\title{
ANALISIS KEWENANGAN PEMERINTAH DAERAH DALAM KEBIJAKAN JAMINAN PRODUK HALAL
}

\author{
Muhammad Ya'rif Arifin* \\ "Dosen Fakultas Hukum Univesitas Muslim Indonesia \\ Email: muh.yarifarifin@umi.ac.id
}

\begin{abstract}
Abstrak
Produk halal kini menjadi trend konsumsi di seluruh dunia, baik di negara muslim maupun non muslim. Tidak kurang dari USD 650 juta transaksi produk halal terjadi setiap tahunnya. Sebagai negara dengan mayoritas berpenduduk muslim, Indonesia sudah seharusnya memperhatikan kebutuhan warganya dalam mengkonsumsi produk halal, salah satunya melalui pemberian jaminan halal atas produk yang dikonsumsi. Lahirnya Undang-Undang Nomor 33 Tahun 2014 tentang Jaminan Produk Halal (UUJPH) sesungguhnya semakin mempertegas betapa mendesaknya persoalan halal-haram dalam rantai produksi dari pelaku usaha hingga sampai di tangan konsumen dan dikonsumsi oleh konsumen, dimana terdapat pula peran pihak perantara seperti distributor, subdistributor, grosir, maupun pengecer sebelum sampai ke tangan kosnumen akhir. Hal inilah yang membuat pemerintah daerah berlomba-lomba untuk menghadirkan peraturan daerah halal (perda halal). Dalam penelitian ini akan dibahas kewenangan pemerintah daerah dalam kebijakan jaminan produk halal diantaranya sejauhmana dan bagaimana kewenangan pemerintah daerah dalam mengatur dan mengawasi produk halal. Tujuan dari penelitian untuk mengetahui sejauh mana kewenangan pemerintah daerah dalam hal pengaturan dan pengawasan terhadap produk halal dalam lingkup daerahnya masing-masing. Jenis penelitian ini merupakan penelitian normatif maka digunakan baik data sekunder maupun data primer. Data sekunder mencakup pada bahan hukum Primer, sekunder, dan tersier. Peran Negara dalam Pelaksanaan Undang-undang Nomor 33 Tahun 2014 sebaiknya lebih masih dilkaukan dengan meminta kepada semua Kepala Daerah membuat peraturan daerah mengenai jaminan produk halal agar amanah Undang-undang Nomor 33 Tahun 2014 bisa terwujud.
\end{abstract}

Kata kunci: Kewenangan; Pemerintah Daerah; Produk Halal 


\begin{abstract}
Halal products are now a consumption trend throughout the world, both in Muslim and non-Muslim countries. No less than USD 650 million transactions for halal products occur every year. As a country with a majority Muslim population, Indonesia should pay attention to the needs of its citizens in consuming halal products, one of which is through the provision of halal guarantees for the products consumed. The enactment of Law Number 33 of 2014 concerning Halal Product Guarantee (UUJPH) actually emphasizes the urgency of the halal-haram issue in the production chain from business actors to reaching consumers and being consumed by consumers, where there is also the role of intermediaries such as distributors, sub-distributors., wholesalers, and retailers before reaching the final consumers. This is what makes local governments better to present halal regional regulations (halal regulations). This type of research is normative research, so it uses both secondary and primary data. Secondary data includes primary, secondary, and tertiary legal materials. The role of the State in the implementation of Law Number 33 of 2014 should still be carried out by asking all Regional Heads to make regional regulations regarding halal product guarantees so that the mandate of Law Number 33 of 2014 can be realized.
\end{abstract}

\title{
Keywords: Authority; Local Government; Halal Products
}

\section{PENDAHULUAN}

Segala bentuk produk yang digunakan dan dikonsumsi oleh masyarakat harus memiliki payung hukum untuk memberikan hak kepemilikan pada suatu produk serta rasa aman dalam mengkonsumsi sesuatu. Produk halal kini menjadi trend konsumsi di seluruh dunia, baik di negara muslim maupun non muslim. Tidak kurang dari USD 650 juta transaksi produk halal terjadi setiap tahunnya. ${ }^{1}$ Di Belanda, sama halnya dengan negara-negara Eropa lainnya, pasar bagi produk makanan halal sedang berkembang, bersesuaian dengan perundang-undangan makanan yang Islamis (Islamic food laws). Jepang juga memiliki perhatian sangat serius terhadap tren halal. Salah satu indikasinya yaitu dengan digelarnya Japan Halal Expo yang memuat produk halal buatan Jepang, sebagai negara dengan mayoritas berpenduduk muslim, Indonesia sudah seharusnya memerhatikan kebutuhan warganya dalam mengkonsumsi produk halal, salah satunya melalui pemberian jaminan halal atas produk yang dikonsumsi. Lahirnya Undang-Undang Nomor 33 Tahun 2014 tentang

\footnotetext{
${ }_{1}^{1}$ Charity, M. L. (2017). Jaminan produk halal di Indonesia (Halal products guarantee in Indonesia). Jurnal Legislasi Indonesia, 14(1), 99-107.
} 
Jaminan Produk Halal (UUJPH) sesungguhnya semakin mempertegas betapa mendesaknya persoalan halal-haram dalam rantai produksi dari pelaku usaha hingga sampai di tangan konsumen dan dikonsumsi oleh konsumen, dimana terdapat pula peran pihak perantara seperti distributor, subdistributor, grosir, maupun pengecer sebelum sampai ke tangan kosnumen akhir. ${ }^{2}$

Menanggapi kebutuhan tersebut, MUI mendirikan LPPOM (Lembaga Pengkajian Pangan, Obat-Obatan dan Kosmetik) pada tahun 1989 untuk memberikan layanan pemeriksaan kehalalan suatu produk pangan, obat-obatan, dan kosmetika. Di sisi lain, kehadiran Undang- Undang Jaminan Produk Halal (UU JPH) yang baru saja ditetapkan telah menjadi payung hukum pelaksanaan JPH di Indonesia, tepatnya UU Nomor 33 Tahun 2014 tentang Jaminan Produk Halal yang selanjutnya akan kami sebut dengan UU JPH. UU tersebut mengamatkan untuk membentuk Badan Penyelenggara Jaminan Produk Halal (BPJPH). Dalam UU JPH produk didefinisikan sebagai barang dan/atau jasa yang terkait dengan makanan, minuman, obat, kosmetik, produk kimiawi,Produk biologi, produk rekayasa genetik, serta barang gunaan yang dipakai, digunakan, atau dimanfaatkan oleh masyarakat. Sedangkan produk halal didefinisikan dengan jelas sebagai Produk yang telah dinyatakan halal sesuai dengan syariat Islam. UU JPH hanya merupakan kepastian hukum terhadap identitas kehalalan suatu produk (pasal 1 ayat (5) UU JPH), sedang yang menetapkan dan atau mewadahi prosesi penetapan produk halal dilakukan oleh beberapa oknum yang terlibat seperti, Auditor Halal, LPH (Lembaga Pemeriksa Halal), MUI serta Kementerian Agama. UU JPH bertujuan untuk memberikan kenyamanan, keamanan, keselamatan, dan kepastian ketersediaan Produk Halal bagi masyarakat dalam mengonsumsi dan menggunakan Produk dan meningkatkan nilai tambah bagi Pelaku Usaha untuk memproduksi dan menjual Produk Halal. Hal inilah yang membuat pemerintah daerah berlomba - lomba untuk menghadirkan peraturan daerah halal (perda halal). Batam menjadi salah satu contoh daerah yang mengeluarkan Peraturan Daerah terkait Perda Halal. Peraturan Daerah Nomor 6 Tahun 2017 Tentang Pembinaan dan Pengawasan Produk Halal dan Higenies merupakan Perda Batam yang saat ini memiliki kekuatan normatif. Perda Halal yang dikeluarkan menimbulkan beberapa pertanyaan terkait kewenangan pemerintah daerah untuk mengeluarkan suatu per undang - undangan yang telah diatur oleh pemerintah pusat dan konsep halal itu sendiri dianggap sebagai bagian dari syariah yang tentunya berkaitan dengan agama, dimana urusan agama merupakan kewenangan absolut pemerintah pusat.

\footnotetext{
${ }^{2}$ Aziz, M. (2017). Perspektif Maqashid Al-Syariah dalam penyelenggaraan jaminan produk halal di Indonesia pasca berlakunya Undang-Undang Nomor 33 tahun 2014 tentang jaminan produk halal. Al Hikmah: Jurnal Studi Keislaman, 7(2), 78-94.
} 


\section{Teori Kewenangan}

Dalam hukum administrasi negara, istilah wewenang sudah tidak asing lagi sebab wewenang adalah bagian penting dalam hukum administrasi. Stroink mengartikan wewenang sebagai kemampuan yuridis dari seseorang. ${ }^{3}$ Rene Seerden dan Frits Stroink menyatakan bahwa ciri utama dari wewenang adalah bahwa wewenang dilaksanakan secara sepihak dan memiliki akibat berlaku untuk semua orang. Hal ini yang membedakan dari hukum privat, di mana dua pihak atau lebih menciptakan kewajiban berdasarkan suatu kesepakatan. Namun demikian, meskipun wewenang dilaksanakan secara sepihak oleh badan atau pejabat pemerintahan, akan tetapi tidak menghalangi warga negara untuk berperan serta dalam proses pembuatan keputusan. ${ }^{4}$ Kewenangan yang di dalamnya terkandung hak dan kewajiban pada hakikatnya merupakan kemampuan untuk melakukan tindakan hukum tertentu, yaitu tindakan-tindakan yang dimaksudkan untuk menimbulkan akibat hukum, dan mencakup mengenai timbul dan lenyapnya akibat hukum. Hak berisi kebebasan untuk melakukan atau tidak melakukan tindakan tertentu atau menurut pihak lain untuk melakukan tindakan tertentu, sedangkan kewajiban memuat keharusan untuk melakukan atau tidak melakukan tindakan tertentu. ${ }^{5}$

\section{Kedudukan Pemerintah Daerah}

Berdasarkan telah sejarah terbentuknya UUD NRI 1945, maka sosok yang pertama merencanakan konsep pemerintahan daerah dalam Sidang BPUPKI pada tanggal 29 Mei 1945 adalah Mr. Mohammed Yamin. Dalam sidang itu, Mohammed Yamin melampirkan rancangan UUD NRI 1945 yang memuat tentang Pemerintahan Daerah, yang berbunyi :

"Pembagian daerah Indonesia atas daerah yang besar dan kecil, dibentuk susunan pemerintahannya ditetapkan dengan Undang - Undang, dengan memandang dan mengingat dasar permusyawaratan dalam sistem pemerintahan negara, dan hak - hak, asal - usul, dan daerah - daerah yang bersifat istimewa". ${ }^{6}$ Istilah "pemerintah" seringkali juga dipertukarkan dengan istilah "pemerintahan". Bahkan, di kalangan para ahli hukum administrasi dan ilmu administrasi kedua istilah tersebut yang sebenarnya merupakan padanan dari istilah "administration", "government", "administratie", "bestuur", dan "regering" masih menjadi perdebatan yang tidak ada habis- habisnya. Istilah "pemerintah" dan "pemerintahan" dapat dibedakan, tetapi tidak dapat dipisahkan, mengingat kriteria "pemerintah" juga

\footnotetext{
${ }^{3}$ A'an, Efendi dan Freddy Poernomo. (2017). HUKUM ADMINISTRASI. Jakarta Timur: Sinar Grafika. ${ }^{4}$ Ibid

5 Rokhim, Abdul. (2013). "KEWENANGAN PEMERINTAH DALAM KONTEKS NEGARA KESEJAHTERAAN (WELFARE STATE)". FH Unismah Malang. Jurnal Ilmiah. Vol XIX, No. 36. 18 Februari 2020.

6 Andi Pangerang, Moenta dan Pradana, Syafa'at Anugrah. (2018). POKOK- POKOK HUKUM PEMERINTAHAN DAERAH. Depok: Raja Grafindo Persada.
} 
bergantung kepada cakupan fungsi "pemerintahan". Istilah "pemerintah" berarti organ yang menjalankan pemerintahan, dan "pemerintahan" merupakan pelaksanaan tugas dan fungsi pemerintah. Prajudi Atmosudirdjo, mendefinisikan pemerintah dapat dipandang sebagai aparatur (mechinary) pemerintah, dan sebagai salah satu fungsi dan proses penyelenggaraan tugas pemerintahan. ${ }^{7}$

Penyelenggaraan pemerintahan dalam suatu negara hukum yang demokratis atau negara demokrasi yang berdasar atas hukum setidaknya memerlukan persyaratan lain agar penerapan asas legalitas dapat memenuhi tujuannya. Dengan memahami peran penting dari penerapan asas legalitas, maka dapat disimpulkan bahwa pemerintah dalam melakukan suatu tindakan atau perbuatan memerlukan dasar tindakan atau perbuatan (asas legalitas) sebagaimana ditentukan dalam ketentuan hukum khususnya undang - undang. Pemerintah tidak boleh atau tidak dapat melakukan suatu tindakan atau perbuatan yang tidak didasari suatu aturan hukum sehingga tindakan atau perbuatan pemerintahan itu dianggap tidak sah dan dikategorikan sebagai tindakan atau perbuatan hukum yang sewenang - wenang adanya. Dalam konsep hukum administrasi dengan tegas dikemukakan, bahwa hubugan hukum yang terjadi antara pemerintah di satu sisi bahwa warga masyarakat di sisi yang lain merupakan hubungan kaum sepihak, dimana kedudukan atau posisi dari pemerintah ialah sebagai subjek yang memerintah sedangkan warga masyarakat sebagai subjek yang diperintah. ${ }^{8}$ Dalam hal ini pemerintah dapat melimpahkan wewenangnya melalui delegasi maupun atribusi.

Sebagai contoh wewenang atribusi oleh pemerintah tertera pada pasal 65 ayat (2) UU No. 23 Tahun 2014 “Dalam melaksanakan tugas sebagaimana dimaksud pada ayat (1) kepala daerah berwenang: a. Mengajukan rancangan perda; b. Menetapkan Perda yang telah mendapat persetujuan bersama DPRD; c. Menetapkan Perkada dan keputusan kepala daerah; d. Mengambil tindakan tertentu dalam keaadan mendesak yang sangat dibutuhkan oleh Daerah dan/atau masyarakat; e. Melaksanakan wewenang lain sesuai dengan ketentuan peraturan perundang - undangan.". Sedangkan sebagai contoh wewenang delegasi oleh pemerintah tertera pada Pasal 10 ayat (2) UU No. 23 Tahun 2014 “Dalam menyelenggarakan urusan pemerintahan absolut sebagaimana dimaksud pada ayat (1), Pemerintah Pusat: a. Melaksanakan sendiri; atau b. Melimpahkan wewenang kepada Instansi Vertikal yang ada di Daerah atau gubernur sebagai wakil Pemerintah Pusat berdasarkan asas Dekosentrasi". ${ }^{9}$

Dari penjelasan di atas sudah jelas kedudukan dari Pemerintah Daerah dimana Pemerintah Daerah diberi wewenang oleh Pemerintah Pusat untuk menjalankan

\footnotetext{
7 Rokhim, Abdul. (2013). “KEWENANGAN PEMERINTAH DALAM KONTEKS NEGARA KESEJAHTERAAN (WELFARE STATE)”. FH Unismah Malang. Jurnal Ilmiah. Vol XIX, No. 36.18 Februari 2020.

${ }^{8}$ Aminuddin Ilmar. 2014. HUKUM TATA PEMERINTAHAN. Jakarta: Kencana.

${ }_{9}^{9}$ A'an, Efendi dan Freddy Poernomo. (2017). HUKUM ADMINISTRASI. Jakarta Timur: Sinar Grafika.
} 
beberapa hal tertentu yang telah diatur dalam UU maupun UUD NRI 1945. Pemerintahan Daerah terdiri dari Kepala Daerah dan DPRD, yang mana DPRD merupakan lembaga perwakilan rakyat daerah dan berkedudukan sebagai unsur penyelenggaraan Pemerintahan Daerah. DPRD berfungsi sebagai Legislasi yaitu Membuat Peraturan Daerah. Sesuai dengan tugas dan wewenang dari DPRD, membentuk Perda yang dibahas dengan Kepala Daerah untuk mendapat persetujuan bersama, membahas dan meyetujui rancangan Perda tentang APBD bersama kepala Daerah, Melaksanakan pengawasan terhadap pelaksanaan Perda dan Peraturan perundang-undangan lainnya, peraturan kepala daerah, APBD, kebijakan pemerintah daerah dalam melaksanakan pembangunan daerah, dan kerjasama internasional di daerah.

\section{Definisi dan Dasar Hukum Produk Halal}

Secara etimologi Halal dalam hukum islam, yang secara harfiah berarti diperbolehkan, bahwa seseorang boleh melakukan suatu kegiatan atau objek tertentu yang lazimnnya dipakai seperti menunjukkan pada makanan atau minuman yang halal dikonsumsi masyarakat. Halal sering dilawankan dengan haram, yaitu segala objek atau kegiatan yang dilarang menurut syariat islam. ${ }^{10}$

Secara terminologi hukum islam, maka istilah dan pengertian Halal berada dalam lingkup hukum islam atau syariat islam yang menjadi pedoman dan/atau tuntutan bagi umat islam khususnya dalam mengkonsumsi makanan dan minuman.

Pasal 28E ayat (1) UUD NRI 1945 menjelaskan bahwa setiap orang diberi kebebasan memeluk agama dan beribadat menurut agamanya. Pada pasal $28 \mathrm{H}$ ayat (1) UUD NRI 1945 menjelaskan bahwa setiap orang berhak hidup sejahtera lahir dan batin, dan mendapatkan lingkungan hidup yang baik dan sehat serta berhak memperoleh pelayanan kesehatan. Sehingga untuk menjamin setiap penduduk untuk beribadah dan menjalankan agamanya serta hidup yang baik dan sehat, negara berkewajiban memberikan perlindungan dan jaminan tentang kehalalan produk yang dikonsumsi dan digunakan masyarakat. Hal inilah yang mendasari lahirnya UU No. 33 Tahun 2014 tentang Jaminan Produk Halal. ${ }^{11}$

Hasil dari penelitian diharapkan dapat menjadi salah satu karya ilmiah yang akan dipublikasikan dan akan memberikan masukan serta menjadi pertimbangan kepada pemerintah daerah untuk ikut aktif berperan dalam hal jaminan produk halal.

\footnotetext{
10 Agus, P. A. (2017). Kedudukan sertifikasi halal dalam sistem hukum nasional sebagai upaya perlindungan konsumen dalam hukum Islam. Amwaluna: Jurnal Ekonomi dan Keuangan Syariah, 1(1), 149-165

11 Abdurrahman Konoras. 2017. JAMINAN PRODUK HALAL DI INDONESIA (PERSPEKTIF PERLINDUNGAN KONSUMEN). Depok: Raja Grafindo Persada.
} 


\section{METODE PENELITIAN}

Sebagai penelitian hukum, penelitian ini merupakan studi terhadap lembaga negara yang ada di Indonesia. Fokus utama dari penelitian ini adalah menganalisis kewenangan pemerintah daerah dalam kebijakan jaminan produk halal. Dengan demikian penelitan ini membutuhkan data sekunder dari studi kepustakaan. Berdasarkan hal tersebut, penelitian ini termasuk dalam jenis penelitian normatif.

Ditinjau dari sifatnya, penelitian ini bersifat deskriptif-preskriptif. Penelitian ini bersifat deskriptif karena berupa pemaparan yang bertujuan untuk memperoleh gambaran (deskripsi) lengkap tentang keadaan hukum yang berlaku di tempat tertentu dan pada saat tertentu yang terjadi dalam masyarakat. Preskriptif dimaksudkan sebagai memberikan argumentasi atas hasil penelitian yang telah diperoleh, yang mana argumentasi ini selanjutnya akan bertujuan untuk memberikan preskripsi, atau penelitian mengenai benar tidaknya dan apa yang seharusnya menurut hukum dilakukan terhadap fakta atau peristiwa hukum yang diperoleh dari hasil penelitian. Untuk mendapatkan informasi dari berbagai aspek mengenai isu yang dibahas dalam penelitian ini, maka penelitian ini menggunakan beberapa metode pendekatan, antara lain yaitu Pendekatan undang-undang (statutory approach), yang dilakukan dengan menelaah undang-undang dan regulasi yang bersangkut paut dengan isu hukum yang sedang ditangani. Pendekatan konseptual (conceptual approach), yang beranjak dari pandangan-pandangan dan doktrindoktrin yang berkembang di dalam ilmu hukum. Pendekatan kasus (Case approach), yang mana dilakukan dengan cara melakukan telaah terhadap kasus yang berkaitan dengan isu yang dihadapi.

Berdasarkan jenis penelitian ini yang merupakan penelitian normatif maka digunakan baik data sekunder maupun data primer. Data sekunder mencakup pada bahan hukum Primer, sekunder, dan tersier yang dapat dijabarkan sebagai berikut Bahan hukum primer merupakan bahan-bahan hukum yang mengikat, dan terdiri dari norma atau kaedah dasar, peraturan dasar, peraturan perundangundangan, bahan hukum yang tidak dikodifikasikan (hukum adat). Yurisprudensi, traktat. Dalam penelitian ini, bahan hukum primer yang digunakan adalah peraturan perundang-undangan yang terkait dengan objek yang diteliti. Bahan hukum sekunder yaitu bahan hukum yang memberikan penjelasan mengenai bahan hukum primer. Bahan hukum sekunder juga berupa semua publikasi tentang hukum yang bukan merupakan dokumen-dokumen resmi. Dalam penelitian ini, bahan hukum sekunder yang digunakan antara lain buku-buku, hasil penelitian, hasil karya dari kalangan hukum, jurnaljurnal hukum, berita online dan lain sebagainya. Kemudian bahan hukum tersier yaitu bahan yang memberikan petunjuk maupun penjelasan terhadap bahan hukum primer dan sekunder, seperti kamus, dan lain sebagainya. 


\section{HASIL PENELITIAN DAN PEMBAHASAN}

\section{Kewenangan Pemerintah Daerah dalam mengatur kebijakan Jaminan Produk Halal}

Halal merupakan istilah dari bahasa Arab yang artinya diperbolehkan, legal, dan sesuai hukum Islam atau syariah. Jika dikaitkan dengan produk farmasetik, makanan, dan minuman, maka halal dapat dimaknai sebagai produk farmasetik, makanan atau minuman yang diperbolehkan untuk dikonsumsi oleh seorang muslim. Berlakunya pelaksanaan MEA (Masyarakat Ekonomi Asia) mulai tahun 2015 menjadi titik penting bagi pelaku UKM (Usaha Kecil Menengah) untuk lebih giat meningkatkan mutu produk dan layanan mereka. Hal tersebut merupakan konsekuensi semakin ketatnya persaingan antar pelaku usaha akibat interaksi global antar-produsen, antar-konsumen, serta antar-produsen dan konsumen, khususnya di wilayah Asia Tenggara (cermati.com). Konsekuensinya, pelaku UKM yang tidak kreatif dan cermat dalam meningkatkan kualitas produknya akan ditinggalkan oleh konsumen yang dapat berdampak pada keberlanjutan UKM tersebut. Kabupaten Malang merupakan salah satu wilayah yang memiliki ribuan UKM yang turut mengembangkan perekonomian daerah. Sebagai salah satu wilayah tujuan wisata internasional, keberadaan UKM sangat mendukung keberadaan kota wisata. UKM khususnya sektor pangan sebagai salah satu bagian integral kota wisata harus mampu memberikan jaminan kualitas produk yang dihasilkan, diantaranya jaminan produk halal, agar konsumen menjadi lebih nyaman dan memperoleh kepuasan. Namun demikan, kenyataan yang terjadi masih lebih dari 50\% UKM khususnya sektor pangan di wilayah Kota dan Kabupaten di Indonesia yang belum memiliki kualitas produk halal. ${ }^{12}$

Sertifikasi Halal adalah suatu proses untuk memperoleh sertifikat halal melalui beberapa tahap pemeriksaan untuk membuktikan bahwa bahan, proses produksi, dan sistem jaminan halal memenuhi standar Lembaga Pengkajian Pangan Obat-obatan dan Kosmetika Majelis Ulama Indonesia (LPPOM MUI). Adapun tujuan sertifikasi halal yaitu untuk memberikan kepastian status kehalalan suatu produk sebagai bentuk pemenuhan hak konsumen. Keyakinan konsumen terhadap kehalalan suatu produk akan mempengaruhi jumlah pembelian konsumen terhadap produk tersebut. Pada masa sebelumnya, pengajuan sertifikasi halal oleh produsen masih bersifat sukarela (voluntary). Akan tetapi, pasca pemberlakuan Undang-Undang Republik Indonesia Nomor 33 Tahun 2014 tentang Jaminan Produk Halal, pengajuan sertifikasi halal oleh produsen bersifat wajib (mandatory). Ketentuan tentang wajibnya sertifikasi halal bagi semua produk tersebut tertuang dalam pasal 4 yang menyatakan bahwa: "Produk yang masuk, beredar, dan diperdagangkan di wilayah Indonesia

\footnotetext{
12 Aziz, M. (2017). Perspektif Maqashid Al-Syariah dalam penyelenggaraan jaminan produk halal di Indonesia pasca berlakunya Undang-Undang Nomor 33 tahun 2014 tentang jaminan produk halal. Al Hikmah: Jurnal Studi Keislaman, 7(2), 78-94.
} 
wajib bersertifikat halal" (Undang-Undang No. 33 Tahun 2014, 2014). Masih merujuk pada UU di atas, pemberlakuan kewajiban sertifikasi halal bagi semua produk di Indonesia akan berlaku pada 5 tahun ke depan sejak UU tersebut ditetapkan. Artinya tahun 2019 merupakan tahun pelaksanaan UU tersebut sehingga semua produk, termasuk produk makanan harus bersertifikasi halal. ${ }^{13}$

Tujuan sertifikasi halal MUI pada dasarnya untuk melindungi hak-hak konsumen dalam hal ini konsumen Muslim. Sertifikasi halal MUI bertujuan untuk menentukan layak atau tidaknya suatu produk mendapat sertifikat halal, dimana penentuan sertifikasi halal dilakukan dalam rapat sidang MUI setelah dilakukannya audit oleh pihak terkait dalam hal ini LPPOM MUI, BPPOM, Dinas Kesehatan dan beberapa instansi terkait. Manfaat Sertifikasi Halal MUI pada dasarnya memeliki beberapa urgensi, selain kepentingan bagi konsumen, pelaku usaha, juga kepentingan bagi pemerintah sendiri dalam hal ini pemerintah daerah dan MUI itu sendiri. ${ }^{14}$ Sertifikasi halal bermanfaat untuk menghilangkan keraguan konsumen terhadap kehalalan produk makanan tersebut. Isu keraguan konsumen terhadap kehalalan produk makanan pernah terjadi di Jatinangor. Misalnya isu penggunaan ayam tiren (mati kemaren), isu tersebut cepat menyebar dikalangan konsumen dan dampaknya sangat merugikan produsen karena akan mengurangi bahkan mematikan penjualan. Dilain pihak, produsen sulit untuk menepis isu tersebut mengingat produsen tidak memiliki bukti sertifikasi halal yang dikeluarkan oleh MUI. ${ }^{15}$ Berdasarkan observasi awal dengan beberapa pelaku UKM khususnya sektor pangan, antara lain: Bapak Jefri sebagai ketua paguyuban UKM rengginang dan kripik singkong di Kecamatan Sumberpucung, dan Ibu sulis UKM jajanan di Kidul Pasar, bahwa mereka belum memiliki sertifikasi produk halal, karena: (1) Belum memahami pentingnya sertifikasi halal dan dampaknya pada UKM; (2) Pelaku UKM belum memahami cara mengajukan sertifikat halal atas produknya; (3) Pelaku UKM belum mengerti kegunaan sertifikasi halal sehingga memilih untuk menunda pengurusannya; dan (4) Pelaku UKM menganggap proses pengajuan sertifikasi halal sangat rumit. Pelaku UKM memiliki motivasi yang kuat untuk mengembangkan usahanya yang lebih berkualitas termasuk jaminan produk halal, agar pemasaran bisa berkembang ke wilayah yang lebih luas, dan dapat di pasarkan di outlet yang selalu menutut adanya

\footnotetext{
${ }^{13}$ Charity, M. L. (2017). Jaminan produk halal di Indonesia (Halal products guarantee in Indonesia). Jurnal Legislasi Indonesia, 14(1), 99-107.

14 Cahyono, D. (2017). PENGARUH RELIGIUSITAS, NORMA SUBYEKTIF DAN PERCEIVED BEHAVIORAL CONTROL TERHADAP NIAT MEMBELI PRODUK MAKANAN RINGAN BERLABEL HALAL (Studi Pada Mahasiswa Universitas Muhammadiyah Purworejo) (Doctoral dissertation, Manajemen-FE).

${ }^{15}$ Akim, A., Purnama, C., Konety, N., \& Shalihah, F. A. (2020). Evaluasi Kegiatan Sosialisasi Produk Impor Halal dan Nonhalal bagi Siswa Madrasah Aliyah Persis 24 Rancaekek Bandung. Agrokreatif: Jurnal Ilmiah Pengabdian kepada Masyarakat, 6(2), 181-194.
} 
jaminan kualitas produk. ${ }^{16}$

Dalam QS. Al-Baqarah ayat : 168 yang menentukan, bahwa Allah SWT mensyari'atkan untuk kita memakan makanan yang halal lagi baik dari apa yang terdapat di bumi. Selanjutnya QS Al-Baqarah, ayat 173 menentukan : bahwa makanan yang haram dimakan adalah bangkai, darah, babi dan binatang yang disembelih tanpa menyebut nama Allah SWT. Ketentuan ini menimbulkan keinginan umat muslim untuk selalu memperhatikan produk yang mereka beli dan/atau konsumsi dengan selalu melihat apakah pada produk tersebut tertera label halal atau tidak. Menurut Jhering,6 kepentingan sebagai sesuatu yang menentukan dalam hukum, khususnya kepentingan masyarakat. Karenanya hukum bertugas menata secara imbang dan serasi antara kepentingan-kepentingan tersebut. Salah satu keseimbangan dan keserasian yang perlu ditata oleh hukum adalah keseimbangan kepentingan antara pengguna produk dengan pelaku usaha yang memiliki produk tersebut. Dan untuk mewujudkan kesimbangan perlindungan kepentingan konsumen dan pelaku usaha sehingga tercipta perekonomian yang sehat diperlukan perangkat peraturan perundang-undangan, salah satunya adalah Undang-undang No.8 Tahun 1999 tentang Perlindungan Konsumen, yang dimaksudkan untuk melindungi konsumen atas produk yang digunakannya atau dikonsumsinya sehinggga tidak timbul rasa kekhawatiran atas mengkonsumsi produk makanan dan/atau minuman. Untuk terlaksananya perlindungan tersebut, Stammler mengatakan bahwa "orang mau berbuat sesuatu, pasti untuk mengejar suatu tujuan" artinya tujuan menentukan perbuatan. Perbuatan sebagai materi diberi bentuknya oleh tujuan yang dikehendaki. Jadi dalam mencapai tujuan melindungi konsumen untuk mendapatkan rasa aman atas produk yang dikonsumsinya maka harus ada perbuatan dari pelaku usaha untuk memberikan perlindungan itu berupa tindakan mensertifikat produknya sebagai produk yang halal untuk dikonsumsi oleh konsumen muslimin. Untuk mewujudkan tindakan pelaku usaha tersebut, maka negara menciptakan seperangkat aturan, yakni dengan mensahkan Undang-Undang No.33 Tahun 2014 tentang Jaminan Produk Halal. Namun itu bukan berarti tindakan negara dalam mewujudkan tindakan pelaku usaha tersebut tidak berhenti sampai dengan disahkan undang-udang tersebut, ada tindakan lain yang harus dilakukan oleh negara sebagai menjamin hak-hak dasar manusia, yaitu hak atas rasa aman dalam mengkonsumsi produk. Tindakan yang harus dilakukan oleh negara sebagai bentuk perlindungan pada hak konsumen terhadap kehalalan suatu produk adalah segera membentuk Lembaga Pemeriksa Halal yang selanjutnya disingkat LPH adalah lembaga yang melakukan kegiatan pemeriksaan dan/atau pengujian terhadap kehalalan produk. Terbentuknya lembaga tersebut berdasarkan Pasal 12 Undang-undang No.33 Tahun 2014, merupakan kerjasama antara pemerintah dan masyarakat, dan berdasarkan Pasal 13 LPH ini harus diajukan oleh lembaga keagamaan Islam berbadan hukum, yang harus memiliki 3

\footnotetext{
${ }^{16}$ Charity, M. L. (2017). Jaminan produk halal di Indonesia (Halal products guarantee in Indonesia). Jurnal Legislasi Indonesia, 14(1), 99-107.
} 
(tiga) orang auditor halal dan memiliki laboratorium atau kesepakatan kerja sama dengan lembaga lain yang memilikilaboratorium. Jadi disinilah peran negara, yakni memback-up terbentuknya lembaga tersebut sehingga pelaksanaan sertifikasi halal atas suatu produk yang diproduksi dan atau yang masuk ke dalam negara, sebagai perwujudan perlindungan terhadap penggunaan produk, sehingga terwujudnya peran negara yaitu melindungi setiap warganegara untuk mencapai keadilan sosial. ${ }^{17}$

Negara mengakui dan menghormati pemerintah daerah sebagaimana diatur dalam undang-undang. Dan negara juga mengakui maupun menghormati kesatuan masyarakat hukum adat dan hak-hak tradisional sesuai dengan perkembangan masyarakat dan prinsip Negara Kesatuan Republik Indonesia. W.S. Saire memaparkan bahwa pemerintah adalah organisasi negara yang muncul dan berjalan kekuasaan. Menurut Wilson, pemerintah adalah kekuatan pengorganisasian, dan tidak selalu dikaitkan dengan organisasi angkatan bersenjata, tapi dua atau sekelompok orang dari berbagai kelompok masyarakat yang diselenggarakan oleh sebuah organisasi untuk mewujudkan tujuan dan sasaran dengan mereka, dengan hal-hal yang memberikan perhatian urusan publik.

UU No. 23 Tahun 2014 tentang Pemerintahan Daerah, menjelaskan bahwa Pemerintahan Daerah adalah penyelenggaraan urusan pemerintahan oleh pemerintah daerah dan dewan perwakilan rakyat daerah menurut asas otonomi dan tugas pembantuan dengan prinsip otonomi seluas-luasnya dalam sistem dan prinsip Negara Kesatuan Republik Indonesia sebagaimana dimaksud dalam Undang-Undang Dasar Negara Republik Indonesia Tahun 1945. Pemerintah Daerah adalah kepala daerah sebagai unsur penyelenggara Pemerintahan Daerah yang memimpin pelaksanaan urusan pemerintahan yang menjadi kewenangan daerah otonom. Dalam kancah pemerintah daerah, kepala daerah sebagai penyelenggara pemerintahan yang mempunyai kewenangan dalam menahkodai kebijakan-kebijakan dan merealisasikan program kerja dalam jangka kurun waktu 5 tahun mendatang. Power yang diberikan oleh undang-undang kepada kepala daerah seyogyanya dapat memberikan efek domino positif (positive domino effect). Kekuasaan kepala daerah bukan hanya sebatas mengatur birokrasi, tetapi UU juga memberikan wewenang dalam membuat kebijakan untuk pengembangan ekonomi daerah yang didasarkan pada pengembangan sektor-sektor unggulan yang memiliki nilai kompetitif dan berorientasi global di masing-masing wilayahnya. Konsep tersebut dimanakan pengembangan ekonomi lokal (Local Economic Development atau PEL). PEL adalah perubahan fundamental pada faktor dan kegiatan yang terkait dengan pengembangan ekonomi daerah. Local economic development pada hakekatnya merupakan proses

\footnotetext{
17 Abdurrahman Konoras. 2017. JAMINAN PRODUK HALAL DI INDONESIA (PERSPEKTIF PERLINDUNGAN KONSUMEN). Depok: Raja Grafindo Persada.
} 
kemitraan antara Pemda dengan para stakeholders. Sektor swasta dapat berpotensi dalam mengelola sumber daya alam, sumber daya manusia, dan kelembagaan. Dengan melalui pola kemitraan dan bertujuan untuk mendorong pertumbuhan kegiatan ekonomi daerah sehingga menciptakan lapangan pekerjaan baru. ${ }^{18}$

Pengembangan ekonomi lokal sebenarnya menitikberatkan pada kebijakan "endogenous development" yaitu mendayagunakan potensi sumber daya manusia, institusional dan fisik setempat. PEL mempunyai tujuan meningkatkan jumlah dan peluang kerja untuk masyarakat daerah. Untuk upaya tersebut, pemerintah daerah bersama kelompok masyarakat dituntut untuk berinisiatif dan tidak hanya berperan pasif. Setiap kebijakan dan keputusan bersifat saling terkait dengan aspek publik lainnya atau multiplayer efek sosial. Local economic development proses pembangunan ekonomi dimana stakeholders endogeneous (pemda, swasta, dan masyarakat) yang berperan aktif dalam pengelolaan sumber daya lokal untuk menciptakan lapangan kerja dan memberikan stimulus pada pertumbuhan ekonomi daerah. Dan prinsip penerapannya ialah stakeholders sangat menentukan keberlanjutan pengembangan ekonomi tersebut. Menurut implementasi, tujuan Lokal economic development meliputi: ${ }^{19}$

- membentuk jaringan kerja kemitraan antar pelaku ekonomi sehingga pemanfaatan potensi dengan meningkatkan kapasitas pasar pada tingkat daerah, regional dan global;

- Meningkatkan kapasitas Lembaga daerah (pemda, swasta, dan masyarakat) dalam pengelolaannya;

- Terjadinya kolaborasi antar Lemba kepentingan (Lembaga, bisnis dan masyarakat); dan

- Secara kolektif dapat mendorong kondisi yang kondusif dalam pertumbuhan ekonomi dan ketenagakerjaan daerah.

Pertumbuhan ekonomi daerah dapat diukur keberhasilannya dilihat dari beberapa lembaga, yaitu:

- Perluasan kesempatan kerja dan usaha bagi masyarakat kecil;

- Meningkatkannya pendapatan bagi masyarakat;

- Berdayanya lembaga usaha mikro dan kecil dalam proses produksi dan pemasaran;

- Berdayanya kelembagaan jaringan kerja kemitraan antara pemerintah, swasta, dan masyarakat setempat.

\footnotetext{
${ }^{18}$ Konety, N., Purnama, C., \& Adilla, M. H. (2018). Pemahaman Usaha Mikro, Kecil dan Menengah (UMKM) di Jatinangor terhadap Kewajiban Sertifikasi Halal Pada Produk Makanan. Kumawula: Jurnal Pengabdian Kepada Masyarakat, 1(1), 31-49.

19 Rokhim, Abdul. (2013). "KEWENANGAN PEMERINTAH DALAM KONTEKS NEGARA KESEJAHTERAAN (WELFARE STATE)". FH Unismah Malang. Jurnal Ilmiah. Vol XIX, No. 36. 18 Februari 2020.
} 


\section{Kewenangan Pemerintah Daerah dalam pengawasan Jaminan Produk Halal}

Sertifikasi halal di Indonesia dalam perkembangan terakhir mengalami pergeseran. Jika selama ini sertifikasi halal ditangani oleh LPPOM MUI yang merupakan lembaga swadaya masyarakat, sejak lahirnya UU Jaminan Produk Halal, penanganan sertifikasi menjadi wewenang negara melalui Badan Penyelenggara Jaminan Produk Halal (BPJPH). MUI memang masih memiliki kewenangan untuk menetapkan halal dan haram. Tetapi proses formalnya, baik pemeriksaan saintifiknya maupun dikeluarkannya sertifikat menjadi wewenang BPJPH. Untuk menjamin setiap pemeluk agama beribadah dan menjalankan ajaran agamanya, Negara berkewajiban memberikan pelindungan dan jaminan tentang kehalalan Produk yang dikonsumsi dan digunakan masyarakat. Jaminan mengenai Produk Halal hendaknya dilakukan sesuai dengan asas perlindungan, keadilan, kepastian hukum, akuntabilitas dan transparansi, efektivitas dan efisiensi, serta profesionalitas. Oleh karena itu, jaminan penyelenggaraan Produk Halal bertujuan memberikan kenyamanan, keamanan, keselamatan, dan kepastian ketersediaan Produk Halal bagi masyarakat dalam mengonsumsi dan menggunakan Produk, serta meningkatkan nilai tambah bagi Pelaku Usaha untuk memproduksi dan menjual Produk Halal. ${ }^{20}$

Pasal 4 UU JPH menyebutkan :

"Produk yang masuk, beredar, dan diperdagangkan di wilayah Indonesia wajib bersertifikat halal." Isi pasal ini bukan diartikan bahwa setiap produk yang dijual oleh pengusaha harus halal dan bukan tidak boleh memperdagangkan yang tidak halal atau haram menurut agama Islam, tetapi maksud dari isi Pasal 4 adalah para pengusaha boleh meperdagangkan barang yang tidak halal, tetapi harus disebutkan bahwa barang tersebut tidak halal. Ketika sudah mendapatkan label halal harus mempertahankan kehalalannya dan menjaga kehalalannya. Intinya para pengusaha bukan tidak boleh memperdagangkan barang haram menurut agama Islam, tetapi harus jujur kalau halal harus punya label halal, sebaiknya kalau ada unsure haram harus dikatakan itu tidak halal. Selanjutnya bahwa, membahas Pasal 4 harus dikaitkan juga dengan isi beberapa Pasal yang mengatur sanksi hukum dari pelanggaran masalah kehalalan, seperti :

Pasal 25, menyebutkan : Pelaku Usaha yang telah memperoleh Sertifikat Halal wajib:

a. mencantumkan Label Halal terhadap Produk yang telah mendapat Sertifikat Halal;

\footnotetext{
${ }^{20}$ Alie, Marzuki, "Perdagangan antar Negara Muslim: Peran Indonesia-Asia dalam Bisnis Halal". Konvensyen Halal Berasaskan Dinar Dirham Sempena Ekspo Perdagangan Dunia Islam 2012, Kelantan Trade Centre, 18 Juni 2012.
} 
b. menjaga kehalalan Produk yang telah memperoleh Sertifikat Halal;

c. memisahkan lokasi, tempat dan penyembelihan, alat pengolahan, penyimpanan, pengemasan, pendistribusian, penjualan, dan penyajian antara Produk Halal dan tidak halal;

d. memperbarui Sertifikat Halal jika masa berlaku Sertifikat Halal berakhir; dan

e. melaporkan perubahan komposisi Bahan kepada BPJPH.

Pasal 25 Undang-Undang Nomor 33 Tahun 2014

" kewajiban pemegang sertifikat halal untuk menyematkan label halal pada produk. Selain itu, pun harus menjaga kehalalan, memperpanjang masa berlaku sertifikat, serta membedakan proses pembuatan produk halal dan tidak halal. Pelaku usaha juga wajib melapor jika ada pengubahan komposisi bahan baku.Adapun sanksinya kalau pemegang sertifikat melanggar pasal tersebut.

Menurut Pasal 22 Undang-Undang Nomor 33 Tahun 2014,

ada tiga jenis hukuman yang diberikan bagi pelanggar.

a. berupa peringatan tertulis.

b. denda administratif dan

c. pencabutan sertifikat halal.

Selanjutnya Pasal 26, menyebutkan ; (1) Pelaku Usaha yang memproduksi Produk dari Bahan yang berasal dari Bahan yang diharamkan sebagaimana dimaksud dalam Pasal 18 dan Pasal 20 dikecualikan dari mengajukan permohonan Sertifikat Halal. (2) Pelaku Usaha sebagaimana dimaksud pada ayat (1) wajib mencantumkan keterangan tidak halal pada produknya. Pengertian dari pasal ini adalah bahwa setiap produk yang akan diedarkan harus halal, dengan mencantumkan label halal dari MUI dan BPJPH. Yang dimaksud dengan "keterangan tidak halal" adalah pernyataan tidak halal yang merupakan bagian tidak terpisahkan dari Produk. Keterangan dapat berupa gambar, tanda, dan/atau tulisan. Pasal ini tidak diartikan bahwa di Indonesia tidak boleh ada produk yang haram untuk diperjualkan, tetapi bagi yang tidak halal maka tidak perlu disertifikasi halal, tetapi cukup dengan memberi label tidak halal.

Sedangkan sanksi pelanggaran ketentuan ini berdasarkan Pasal 27 UU Nomor 33 Tahun 2014, yaitu :
a. sanksi teguran lisan,
b. peringatan tertulis, dan
c. denda administratif

Mengingat mayoritas rakyat Indonesia adalah masyarakat Islam, yang sangat membutuhkan perlindungan dari Negara terhadap barang-barang yang tidak halal 
dan tidak mempunyai lebel halal, maka Negara mengajak masyarakat untuk berperan serta melakukan pengawasan terhadap produk-produk yang bererdar dipasaran baik dari luar maupun dalam negeri, bahkan Negara akan memberikan penghargaan kepada masyarakat yang ikut serta secara aktif dalam Pengawasan tersebut. Seperti yang disebutkan dalam Pasal 53 yaitu:

(1) Masyarakat dapat berperan serta dalam penyelenggaraan JPH.

(2) Peran serta masyarakat sebagaimana dimaksud pada ayat (1) dapat berupa: a. melakukan sosialisasi mengenai JPH; dan b. mengawasi Produk dan Produk Halal yang beredar.

(3) Peran serta masyarakat berupa pengawasan Produk dan Produk Halal yang beredar sebagaimana dimaksud pada ayat (2) huruf $b$ berbentuk pengaduan atau pelaporan ke BPJPH. Selanjutnya Pasal 54, menyebutkan : BPJPH dapat memberikan penghargaan kepada masyarakat yang berperan serta dalam penyelenggaraan JPH. Sebagai wujud apresiasi maka BPJPH sebagai lembaga penyelenggara Jaminan Produk Halal dapat memberikan penghargaan kepada masyarakat yang berperan aktif dalam penyelenggaraan Jaminan Produk Halal.

\section{KESIMPULAN}

Peran Negara dalam Pelaksanaan Pasal 4 UU No.33 Tahun 2014 tentang Jaminan Produk Halal, Semula oleh lembaga MUI (Majelis Ulama Indonesia). Tetapi sejak diundangkannya UU.No.33 Tahun 2014 tentang Jaminan Produk Halal wewenang tersebut dialihkan kepada Badan Penyelenggara Jaminan Produk Halal (BPJPH) sejak Oktober tahun 2017. Dalam rangka menjamin pelaksanaan penyelenggaraan Jaminan Produk Halal sebaiknya Kepala Daerah menerbitkan perarturan daerah mengenai jaminan produk halal sebagia instrument penegakan jaminan produk halal di Indonesia sesuai dengan amanah UU No. 33 Tahun 2014.

Peran serta Masyarakat dalam Jaminan Produk Halal sangat diharapkan pemerintah. Terbukti ada 2 Pasal yang mengatur dan mengajak masyarakat untuk berperan serta dalam mengawasi peredaran produk halal. Hasil penelitian penulis bahwa masyarakat berkeinginan untuk membantu pemerintah dalam penyelenggaraan jaminan Produk Halal. Dan antusias masyarakat terhadap program ini terlihat dari data yang penulis peroleh dimana $75 \%$ masyarakat muslim bersedia untuk menjadi anggota LPH, dan 100\% bersedia untuk mendukung program-program pemerintah terkait sosialisasi sertifikasi produk halal. Oleh karena itu agar Segera dilakukan sosialisasi UU Jaminan Produk Halal, karena semakin banyaknya barang barang dari produk luar negeri yang tidak jelas kehalalannya, sehingga masyarakat lebih waspada dan hati-hati. 


\section{DAFTAR PUSTAKA}

Abdurrahman Konoras. 2017. JAMINAN PRODUK HALAL DI INDONESIA (PERSPEKTIF PERLINDUNGAN KONSUMEN). Depok: Raja Grafindo Persada.

Agus, P. A. (2017). Kedudukan sertifikasi halal dalam sistem hukum nasional sebagai upaya perlindungan konsumen dalam hukum Islam. Amwaluna: Jurnal Ekonomi dan Keuangan Syariah, 1(1), 149-165

Akim, A., Purnama, C., Konety, N., \& Shalihah, F. A. (2020). Evaluasi Kegiatan Sosialisasi Produk Impor Halal dan Nonhalal bagi Siswa Madrasah Aliyah Persis 24 Rancaekek Bandung. Agrokreatif: Jurnal Ilmiah Pengabdian kepada Masyarakat, 6(2), 181-194.

Alie, Marzuki, "Perdagangan antar Negara Muslim: Peran Indonesia-Asia dalam Bisnis Halal". Konvensyen Halal Berasaskan Dinar Dirham Sempena Ekspo Perdagangan Dunia Islam 2012, Kelantan Trade Centre, 18 Juni 2012.

Aminuddin Ilmar. 2014. HUKUM TATA PEMERINTAHAN. Jakarta: Kencana.

A'an, Efendi dan Freddy Poernomo. (2017). HUKUM ADMINISTRASI. Jakarta Timur: Sinar Grafika.

Andi Pangerang, Moenta dan Pradana, Syafa'at Anugrah. (2018). POKOK- POKOK HUKUM PEMERINTAHAN DAERAH. Depok: Raja Grafindo Persada.

Apriyantono, Anton dan Nurbowo. Panduan Belanja dan Konsumsi Halal. Jakarta: Khairul Bayaan, 2003.

Asrorun Ni'am Sholeh, "Halal Jadi Tren Global” dalam GATRA Edisi 29 Juli 2015, h. 34-35.

Aziz, M. (2017). Perspektif Maqashid Al-Syariah dalam penyelenggaraan jaminan produk halal di Indonesia pasca berlakunya Undang-Undang Nomor 33 tahun 2014 tentang jaminan produk halal. Al Hikmah: Jurnal Studi Keislaman, 7(2), 7894.

Cahyono, D. (2017). PENGARUH RELIGIUSITAS, NORMA SUBYEKTIF DAN PERCEIVED BEHAVIORAL CONTROL TERHADAP NIAT MEMBELI PRODUK MAKANAN RINGAN BERLABEL HALAL (Studi Pada Mahasiswa Universitas Muhammadiyah Purworejo) (Doctoral dissertation, Manajemen-FE).

Charity, M. L. (2017). Jaminan produk halal di Indonesia (Halal products guarantee in Indonesia). Jurnal Legislasi Indonesia, 14(1), 99-107.

Direktori Produk Halal 2013-2014. Jakarta: Direktorat Urusan Agama Islam dan 
Pembinaan Syariah, Ditjen Bimbingan Masyarakat Islam Kementerian Agama RI, 2013.

Ija Suntana, Politik Hukum Islam, Bandung: CV Pustaka Setia, 2014

Janzuni, Legislasi Hukum Islam di Indonesia, Bandung: PT Citra Aditya Bhakti, 2005.

Konety, N., Purnama, C., \& Adilla, M. H. (2018). Pemahaman Usaha Mikro, Kecil dan Menengah (UMKM) di Jatinangor terhadap Kewajiban Sertifikasi Halal Pada Produk Makanan. Kumawula: Jurnal Pengabdian Kepada Masyarakat, 1(1), 3149.

Masdar Farid Masudi, Syarah Konstitusi UUD 1945 dalam Perspektif Islam, Jakarta: Pustaka Alvabet, 2010

Naskah Akademik RUU-JPH

Peraturan Pemerintah Nomor 58 Tahun 2001 tentang Pembinaan dan Pengawasan Penyelenggaraan Perlindungan Konsumen.

Rohman, Abdul. Pengembangan dan Analisis Produk Halal. Yogyakarta: Pustaka Pelajar, 2012.

Rokhim, Abdul. (2013). "KEWENANGAN PEMERINTAH DALAM KONTEKS NEGARA KESEJAHTERAAN (WELFARE STATE)”. FH Unismah Malang. Jurnal Ilmiah. Vol XIX, No. 36. 18 Februari 2020.

Silalahi, Ulber. Metode Penelitian Sosial. Bandung: Refika Aditama, 2010. Zulham. Hukum Perlindungan Konsumen. Jakarta: Kencana Prenada Media Group, 2013.

Sofyan Hasan, Sertifikasi Halal dalam Hukum Positif, Regulasi dan Implementasinya di Indonesia, Yogyakarta: Aswaja Pressindo, 2014

Tulus Abadi Dkk. Tim Pengkajian Hukum tentang Peran Serta Masyarakat dalam pemberian Informasi Halal, Kementerian Hukum dan Hak Asasi Manusia Badan Pembinaan Hukum Nasional, Jakarta: 2011

Undang - Undang tentang Jaminan Produk Halal, UU No. 33 Tahun 2014.

Undang - Undang tentang Pemerintahan Daerah, UU No. 23 Tahun 2014.

Undang - Undang Dasar Negara Republik Indonesia Tahun 1945, Pasal 28E ayat (1).

Undang - Undang Dasar Negara Republik Indonesia Tahun 1945, Pasal 28H ayat (1).

Undang - Undang Nomor 31 Tahun 2019 tentang Peraturan Pelaksanaan Undang Undang Nomor 33 Tahun 2014 tentang Jaminan Produk Halal. 